\title{
Measuring Total Classical Pathway and Activities of Individual Components of the Mouse Complement Pathway
}

Wioleta M. Zelek*

\author{
Division of Infection and Immunity and Dementia Research Institute, School of Medicine, Cardiff \\ University, Wales, United Kingdom \\ *For correspondence: zelekw@cardiff.ac.uk
}

\begin{abstract}
[Abstract] The complement system is a central component of innate immunity, responsible for recognition and killing of bacteria by tagging invaders through opsonisation, thereby promoting phagocytosis, and by direct lysis. Complement activity is routinely measured using functional assays that utilise erythrocytes as targets. The classical pathway haemolytic assay (CH50) with antibody sensitised sheep erythrocytes as target is used worldwide in clinical and research laboratories to measure complement activity in human and rodent sera. While there are no particular limitations in the human assay, measuring complement in mouse serum is more difficult and usually requires large amounts of serum, which is challenging to collect in experiments. In particular, it is challenging to measure the activities of individual mouse complement proteins. To overcome this hurdle, we have developed protocols that employ human sera depleted of single complement proteins as the source of the other complement proteins and test mouse serum to restore the relevant component. This simple haemolytic assay is a useful tool for confirming natural or engineered complement deficiencies and complement dysregulation in mouse models.
\end{abstract}

Keywords: Complement, Haemolytic, Assay, Classical, CH50, Depleted sera, Mouse

[Background] Complement comprises more than 30 plasma and membrane-bound proteins that interact to induce a series of inflammatory responses to defend against infection, prime innate immunity and modulate adaptive responses. The complement cascade is activated by three pathways: classical (CP), lectin and alternative (Morgan et al., 2015; Zelek et al., 2019a). The CP was the first to be discovered when investigating the bacterolytic properties of serum in the $19^{\text {th }}$ century. More recent studies have shown that the complement cascade is functionally and structurally conserved in mammals, with the majority of components working across species (Slodkowicz et al., 2020; Moleón et al., 2006). $\mathrm{CP}$ is triggered by antigen-bound antibodies on surfaces; $\mathrm{C} 1$ binds and initiates a cascade with sequential generation of the $\mathrm{CP} C 3$ convertase $\mathrm{C} 4 \mathrm{~b} 2 \mathrm{a}$ and $\mathrm{C} 5$ convertase $\mathrm{C} 4 \mathrm{~b} 2 \mathrm{a} 3 \mathrm{~b}$. The $\mathrm{C} 5$ convertase cleaves $\mathrm{C} 5$, releasing the $\mathrm{C} 5 \mathrm{a}$ anaphylatoxin and initiating the terminal pathway through $\mathrm{C} 5 \mathrm{~b}$; this binds $\mathrm{C} 6$ and $\mathrm{C} 7$, and the trimolecular C5b-7 complex attaches to the target surface. C8 and multiple copies of C9 are recruited to build a transmembrane pore (Podack et al., 1984; Serna et al., 2016; Menny et al., 2018). The complement system evolved to protect from pathogens; however, over-activation of complement drives inflammation in many diseases, including renal, autoimmune and neurological diseases (Zelek et al., 2019a; Carpanini et al., 2019). Emerging evidence of roles of complement 
activation in diverse diseases has triggered an explosion of interest in developing new complement targeting drugs and generated a need for testing in animal models. It is therefore important to have simple and robust assays measuring complement activity in rodents and other model species. Although the traditional $\mathrm{CH} 50$ assay, developed more than 70 years ago (Rice et al., 1952; Mayer et al., 1967), is well respected and used in research and clinical settings to measure human complement activity, its application for measuring mouse complement is limited because the "classical" targets, antibodysensitised sheep erythrocytes (ShEA), are poor activators of mouse complement necessitating the use of high amounts of mouse serum required (typically, $25-50 \%$ concentration in assay). The utility of the assay for mouse can be improved by inclusion of an additional sensitisation step, incubating the ShEA with mouse anti-rabbit lgG, but serum requirement remains high (Zelek et al., 2019b) (Figure 1).

Here I provide modified haemolysis assay protocols for measuring the activity of individual components of mouse complement that require $\sim 10$-fold less mouse serum by combination with human depleted sera (Figure 1). Because of the high functional conservation in complement proteins between man and rodent, the test mouse component functionally restores haemolysis in the depleted human serum, providing a titratable assay.

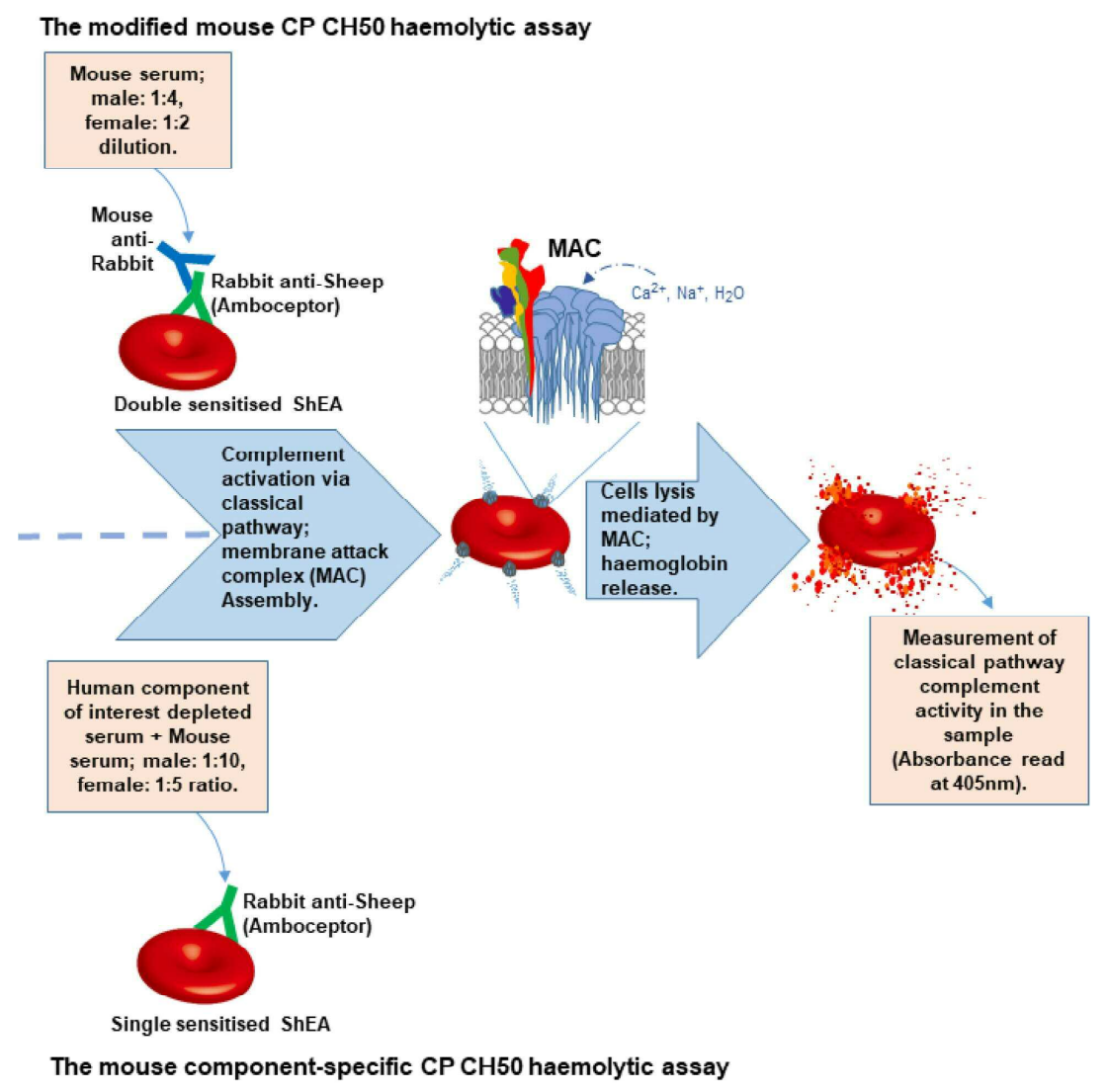

Figure 1. Schematic of mouse classical pathway (CP) CH50 haemolytic assays. Top panel: diagram of modified $\mathrm{CP}$ CH50 haemolytic assay utilising double sensitised ShEA and high amounts of mouse serum (typically $25 \%$ male, $50 \%$ female). Bottom panel: diagram of the mouse componentspecific CP CH50 haemolytic assay utilising 10\% human serum depleted of the component of interest and different amounts of mouse serum as source of the component. MAC, membrane attack 
complex; ShEA, sheep erythrocytes sensitised with amboceptor.

\section{Materials and Reagents}

1. Pipette tips: $1,250 \mu \mathrm{l}, 200 \mu \mathrm{l}, 10 \mu \mathrm{l}$ (Sapphire, Greiner Bio-One, catalog numbers: $750-257,737-$ $257,771-257$, respectively)

2. $1.5 \mathrm{ml}$ Eppendorf tubes (Greiner Bio-One, catalog number: 616261)

3. $50 \mathrm{ml}$ Falcon tubes (Cell Star, Greiner Bio-One, catalog number: 227261)

4. $15 \mathrm{ml}$ Falcon tubes (Cell Star, Greiner Bio-One, catalog number: 188271)

5. Membrane filter, $0.22 \mu \mathrm{m}$ pore size (Millipore, MF-Millipore ${ }^{\mathrm{TM}}$, catalog number: GSWP04700)

6. Adhesive film for microplates, polyester film non-sterile (VWR, catalog number: 60941-062)

7. 96-well U-bottom clear microplate (Greiner Bio-One, catalog number: 650101)

8. 96-well F-bottom clear microplate (Greiner Bio-One, catalog number: 655101)

9. Reagents reservoirs (Pierce, ThermoFisher Scientific, catalog number: 15075)

10. Normal human serum pool (NHS), stored in aliquots at $-80^{\circ} \mathrm{C}$ (in house prepared from freshly collected blood from healthy volunteers, $n=3$ )

11. Normal male mouse serum (NMS) stored at $-80^{\circ} \mathrm{C}$ (in house prepared from freshly collected blood, $\mathrm{n}=22$ ). The complement lytic activity in C57BL/6 female mouse is significantly reduced compared to male (in our hands $\sim 40-50 \%$ ) due to higher production of androgen and estrogen hormones that lower levels of terminal pathway proteins C5 and C6 (Churchill et al., 1967; Kotimaa et al., 2016).

12. Normal human C5-depleted serum (C5D; C5 used here as an exemplar; this method can be used to deplete any other complement components from the serum), generated by passage of NHS (in house prepared from freshly collected blood from healthy volunteers, $n=3$ ) over an immunodepletion column comprising an in-house anti-C5 mAb immobilised on sepharose (GE Healthcare, $1 \mathrm{ml}$ HiTrap NHS-Activated HP, catalog number: 17-0716-01), stored in aliquots at $-80^{\circ} \mathrm{C}$.

13. HEPES (Fisher Chemicals, Fisher Scientific, catalog number: BP310-500)

14. Magnesium chloride (Acros Organics, Fisher Scientific, catalog number: 2232/0010)

15. Calcium chloride (Fisher Chemicals, Fisher Scientific, catalog number: $C / 1400 / 53$ )

16. Sodium chloride (Alfa Asear, Fisher Scientific, catalog number: 12314)

17. Sodium hydroxide (Macron Fine Chemicals, Fisher Scientific, catalog number: 7066-33)

18. Sheep Blood in Alsever's Solution (TCS Biosciences, catalog number: SB069) as a source of sheep erythrocytes (ShE); over time, the ShE will pellet at the bottom of the Nalgene bottle, and the pelleted ShE are harvested for assaying

19. Rabbit anti-ShE antiserum (Siemens Amboceptor, Cruinn Diagnostics, catalog number: ORLC25)

20. Mouse anti-Rabbit IgG $(\mathrm{H}+\mathrm{L})$ Cross-Adsorbed Secondary Antibody (ThermoFisher Scientific, Invitrogen, catalog number: 31213)

21. Alsever's solution (Merk, Sigma-Aldrich, catalog number: A3551-1L) 
22. Purified human $\mathrm{C} 5$, stored at $-80^{\circ} \mathrm{C}$, by-product of the $\mathrm{C} 5 \mathrm{D}$ serum preparation (also available at Hycult Biotech, catalog number: HC2141)

23. HBS buffer (see Recipes)

\section{Equipment}

1. Pipettes (Eppendorf, model: Eppendorf Research ${ }^{\circledR}$ plus, catalog numbers: 3123000918 , 3125000060)

2. Incubator (Memmert 0135)

3. Shaking water bath (VWR, model: 462-0494)

4. Centrifuge (ThermoFisher Scientific, Heraeus megafuge 40R, TX-1000 rotor)

5. Microplate reader (Tecan, Infinite F50)

6. Analytical balance (A\&D Company Limited, model: FZ-300i-EC)

7. Stirrer (Stuart, Bio-Cote)

8. $\mathrm{pH}$ meter (Jenway Scientific Laboratories Supplies SLS, model: RS232)

\section{Software}

1. GraphPad Prism (Graphpad Holdings, LLC)

\section{Procedure}

Note: All procedures are performed in the standard laboratory settings. All chemicals used are of analytical grade.

A. Serum preparation

Human and animal sera were prepared in-house from freshly collected blood. For human, blood was collected into glass bottles, clotted at room temperature (RT) for $1 \mathrm{~h}$, and then placed on ice for $2 \mathrm{~h}$ for clot retraction prior to centrifugation $\left(2,000 \times \mathrm{g}\right.$ for $15 \mathrm{~min}$ at $\left.4^{\circ} \mathrm{C}\right)$ and harvesting of serum. For mouse, blood was collected into Eppendorf tubes by tail bleeding, placed on ice immediately after harvest and clotted for $2 \mathrm{~h}$ on ice prior to serum harvest. Sera were filtered (via $0.22 \mu \mathrm{m}$ filter) and stored in aliquots $(100$ or $500 \mu \mathrm{l})$ at $-80^{\circ} \mathrm{C}$.

B. Preparation of HBS buffer HEPES-buffered saline (HBS; $0.01 \mathrm{M} \mathrm{HEPES,} 0.15 \mathrm{M} \mathrm{NaCl}, 135 \mu \mathrm{M} \mathrm{CaCl}_{2}, 1 \mathrm{mM} \mathrm{MgCl}$, final pH 7.4) prepared as previously described (Zelek et al., 2018). 
C. Preparation of Antibody-Sensitized Sheep Erythrocytes for Classical Pathway Assay (ShEA)

1. Pipette $400 \mu \mathrm{l}$ of the settled ShE pellet (see Materials \#18), and add to $20 \mathrm{ml} \mathrm{HBS}$ with gentle mixing.

2. Wash the ShE three times in $20 \mathrm{ml} \mathrm{HBS}$ by centrifugation $\left(1,500 \times \mathrm{g}, 10 \mathrm{~min}, 4^{\circ} \mathrm{C}\right)$ and resuspension in $20 \mathrm{ml}$ fresh HBS with gentle mixing. The supernatant, red in first wash, should be clear by the final wash, confirming that the cells are viable for use.

3. Resuspend the final pellet in $10 \mathrm{ml}$ HBS containing Amboceptor (usually 1:2,000 dilution, although working dilution should be titrated for each new batch to optimally sensitise without causing agglutination) at $37^{\circ} \mathrm{C}$; add the solution slowly with mixing. Incubate the mixture for $30 \mathrm{~min}$ at $37^{\circ} \mathrm{C}$, shaking in a water bath.

4. Wash the sensitised ShE (ShEA) as above and resuspend the final pellet in $20 \mathrm{ml} \mathrm{HBS}$. ShEA can be stored at $4^{\circ} \mathrm{C}$ for up to one week or in igloo in a cold room $\left(0^{\circ} \mathrm{C}\right.$ equivalent) for up to two weeks with ice replaced as necessary.

D. Calculating concentration of ShEA

1. Aliquot the ShEA suspension into wells of a 96 -well U-bottomed plate $(50 \mu /$ well $)$, and add 100 $\mu \mathrm{l} / \mathrm{well}$ of $\mathrm{ddH}_{2} \mathrm{O}$ (in triplicate).

2. Centrifuge plate $\left(1,500 \times \mathrm{g}, 3 \mathrm{~min}, 4^{\circ} \mathrm{C}\right)$.

3. Transfer $100 \mu \mathrm{l}$ of the supernatant into an F-bottom plate. The supernatant contains $\mathrm{ddd}_{2} \mathrm{O}$ and haemoglobin (red in colour) released from the ShEA. All cells should be lysed; ghost cells are not visible to the naked eye.

4. Measure the absorbance of the supernatants at $405 \mathrm{~nm}$ using the plate reader (lysed cells release haemoglobin, which creates a measurable red colour readout); the absorbance of OD1 equates to $8.5 \times 10^{7} / \mathrm{ml}$ original concentration.

E. Testing ShEA for sensitivity to lysis by human serum

1. In 96-well U-bottomed plate, prepare NHS serial dilutions (in triplicate; 10-0\%) in HBS (50 $\mu \mathrm{l} /$ well), and add $50 \mu \mathrm{l}$ of $2 \%$ ShEA (prepared as described above, see section C) and $50 \mu \mathrm{l}$ of HBS (total volume per well $=150 \mu$ l) into each well.

2. Prepare controls (in triplicate):
a. $0 \%$ lysis: $50 \mu \mathrm{l} \mathrm{ShEA}+100 \mu \mathrm{l}$ of HBS
b. $100 \%$ lysis: $50 \mu \mathrm{LhEA}+100 \mu \mathrm{l}$ of $\mathrm{ddH}_{2} \mathrm{O}$

3. Seal the plate and incubate at $37^{\circ} \mathrm{C}$ for $30 \mathrm{~min}$.

4. Centrifuge plate $\left(1,500 \times \mathrm{g}, 3 \mathrm{~min}, 4^{\circ} \mathrm{C}\right)$.

5. Transfer $100 \mu \mathrm{l}$ of supernatant into an F-bottom plate.

6. Measure the absorbance of the supernatants at $405 \mathrm{~nm}$ using the plate reader. Optimally sensitised ShEA will be fully lysed ( $100 \%$ compared to controls) by NHS at $10 \%$ and above, under these conditions. 
F. Further sensitisation of ShEA for mouse classical Pathway Assay (ShEA-m)

1. Take $5 \mathrm{ml}$ of the $2 \%$ ShEA in HBS.

2. Pellet the cells (centrifuge at $1,500 \times g$ for $10 \mathrm{~min}, 4^{\circ} \mathrm{C}$ )

3. Add pre-warmed (at $37^{\circ} \mathrm{C}$ in the water bath) mouse anti-rabbit IgG at a final concentration of 25 $\mu \mathrm{g} / \mathrm{ml}$ in $5 \mathrm{ml}$ of HBS and resuspend the cells.

4. Incubate at $37^{\circ} \mathrm{C}$ in the shaking water bath for $30 \mathrm{~min}$.

5. Wash the cells three times (in $20 \mathrm{ml} \mathrm{HBS}$ by centrifugation; $1,500 \times \mathrm{g}, 10 \mathrm{~min}$ at $4^{\circ} \mathrm{C}$ ) to remove excess antibody, resuspend in $5 \mathrm{ml} \mathrm{HBS}$; ShEA-m can be stored on ice for up to two weeks.

6. Test the ShEA-m for sensitivity to lysis by mouse serum using dilutions of NMS from 100 to $0 \%$ ( $100 \%$ equates to a final dilution of $33 \%$ in the assay). In a $96-w e l l$ U-bottomed plate, prepare serial dilutions (in triplicate) between 100 and $0 \%$ NMS (50 $\mu \mathrm{l} /$ well) in HBS and add $50 \mu \mathrm{l}$ of $2 \%$ ShEA-m and $50 \mu \mathrm{l}$ of HBS (total volume per well $=150 \mu \mathrm{l}$ ) into each well.

7. Prepare controls (in triplicate):

a. $0 \%$ lysis: $50 \mu \mathrm{l} \mathrm{ShEA-m}+100 \mu \mathrm{l}$ of HBS

b. $100 \%$ lysis: $50 \mu \mathrm{l}$ ShEA-m $+100 \mu$ of $\mathrm{ddH}_{2} \mathrm{O}$

8. Seal the plate and incubate at $37^{\circ} \mathrm{C}$ for $30 \mathrm{~min}$.

9. Centrifuge plate $\left(1,500 \times \mathrm{g}, 3 \mathrm{~min}, 4^{\circ} \mathrm{C}\right)$.

10. Transfer $100 \mu \mathrm{l}$ of supernatant into an F-bottom plate.

11. Measure the absorbance of the supernatants at $405 \mathrm{~nm}$ using the plate reader. Optimally sensitised ShEA-m will be fully lysed (100\% compared to controls) by NMS at $100 \%$ under these conditions.

G. Assay method - modified mouse $\mathrm{CP}$ CH50 assay

1. In a U-bottom plate, prepare a serial dilution series (in triplicate) of NMS (100-0\%; $50 \mu \mathrm{l} /$ well). Add $50 \mu \mathrm{l}$ of $2 \%$ ShEA-m, followed by $50 \mu \mathrm{l}$ of HBS (total volume per well, $150 \mu \mathrm{l}$; final serum concentration, 33-0\%).

2. Prepare controls (in triplicate):

a. $0 \%$ lysis: $50 \mu \mathrm{l} \mathrm{ShEA-m}+100 \mu \mathrm{l}$ of HBS

b. $100 \%$ lysis: $50 \mu$ ShEA-m $+100 \mu$ l of $\mathrm{ddH}_{2} \mathrm{O}$

3. Seal the plate and incubate at $37^{\circ} \mathrm{C}$ for $30 \mathrm{~min}$.

4. Centrifuge the plate at $1,500 \times g$ for $3 \mathrm{~min}$ at $4^{\circ} \mathrm{C}$.

5. Using a 12-channel multipipette, transfer $100 \mu$ l supernatant from each well to an F-bottom plate, taking care not to disturb the pelleted unlysed ShEA-m.

6. Measure the absorbances at $405 \mathrm{~nm}$ using plate reader within $10 \mathrm{~min}$.

7. Calculate haemolysis; refer to Figure 2 for example calculations.

Please see the step-by-step assay workflow in Figures 3 and 4 below. 
A

\begin{tabular}{|c|c|c|c|c|c|c|c|c|c|c|c|}
\hline \multirow{2}{*}{$\begin{array}{r}\text { Plate Layout } \\
\text { NMS }\end{array}$} & & \multicolumn{4}{|c|}{ Raw data $\mathrm{A} 405 \mathrm{~nm}$} & \multicolumn{2}{|l|}{ Mean replicates } & \multicolumn{4}{|l|}{ \% Lysis } \\
\hline & Controls & & & & & \begin{tabular}{|c|} 
NMS \\
\end{tabular} & Controls & & & & \\
\hline & Sh[A-m + IIDS & 0.9993 & 1.0332 & 0.0419 & 0.0491 & 1.0163 & 0.0455 & 98.24 & 101.73 & -0.37 & 0.37 \\
\hline 50.00 & ShEA-m+ddH2C & 0.9104 & 0.8953 & 1.0230 & 1.0098 & 0.9029 & 1.0164 & 89.08 & 87.53 & & 99.32 \\
\hline 25.00 & & 0.6715 & 0.6973 & & & 0.6844 & & 64.48 & $6 / .13$ & & \\
\hline 12.50 & & 0.2530 & 0.2632 & & & 0.2581 & & 21.37 & 22.42 & & \\
\hline 6.35 & & 0.1592 & 0.1486 & & & 0.1540 & & 11.72 & 10.62 & & \\
\hline 3.13 & & 0.0964 & 0.0855 & & & 0.0910 & & 5.24 & 4.12 & & \\
\hline 1.57 & & 0.0558 & 0.0557 & & & 0.0558 & & 1.06 & 1.05 & & \\
\hline 0.00 & & 0.0493 & 0.0501 & & & 0.0497 & & 0.39 & 0.47 & & \\
\hline
\end{tabular}

B

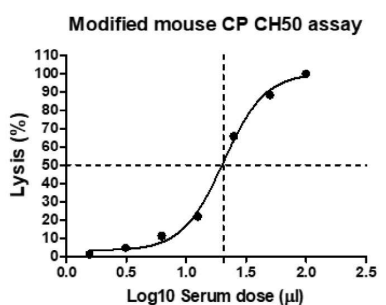

Figure 2. Example data of mouse CP CH50 assay utilising double sensitised ShEA-m. A. Assay plate setup and calculations; red colour indicates the signal intensity. B. CH50 plotted for NMS dilution series (100-0\%). The dotted lines show the serum dose to give $50 \%$ ShEA lysis.

NMS: normal mouse male serum.

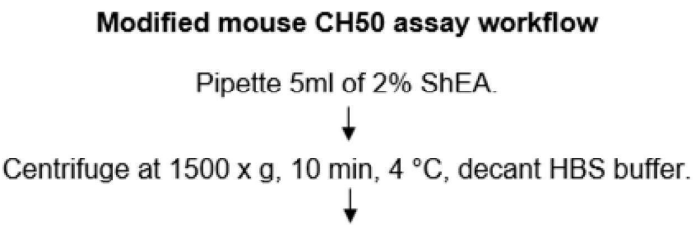

Add pre-warmed $5 \mathrm{ml}$ of HBS containing mouse anti-rabbit lgG (Invitrogen \#31213) at final concentration of $25 \mu \mathrm{g} / \mathrm{ml}$.

Incubate at $37^{\circ} \mathrm{C}$ in shaking water bath for 30 minutes.

Centrifuge at $1500 \times \mathrm{g}, 10 \mathrm{~min}, 4^{\circ} \mathrm{C}$, decant buffer, replace with fresh (repeat $\times 3$ ).

$\downarrow$

Resuspend the final washed ShEA-m pellet in $5 \mathrm{ml}$ HBS, store on wet ice $\left(0^{\circ} \mathrm{C}\right)$.

$\downarrow$

In U-shape plate prepare serial dilution series of NMS in HBS;

( $100-0 \%$, in triplicate; $50 \mu \mathrm{l} /$ well).

Add $50 \mu$ l of $2 \%$ ShEA-m in HBS to each well.

Add $50 \mu \mathrm{l} \mathrm{HBS}$ to each well (total volume per well is $150 \mu \mathrm{l}$ ).

Seal the plate and incubate for 30 minutes at $37^{\circ} \mathrm{C}$.

Stop the reaction by centrifuging the plate at $1500 \times \mathrm{g}$ at $4^{\circ} \mathrm{C}$ for 3 minutes.

Transfer $100 \mu \mathrm{l}$ of the supernatant (without disturbing the pellets) from each well into $\mathrm{F}$-bottom plate.

Read absorbance at $405 \mathrm{~nm}$.

Calculate the percentage lysis as follow;

(Sample $A_{405}$ - Background $A_{405}$ ) / (Maximum $A_{405}-$ Background $\left.A_{405}\right)^{\star} 100 \%$.

\section{Figure 3. Workflow of the modified mouse CP CH50 assay}



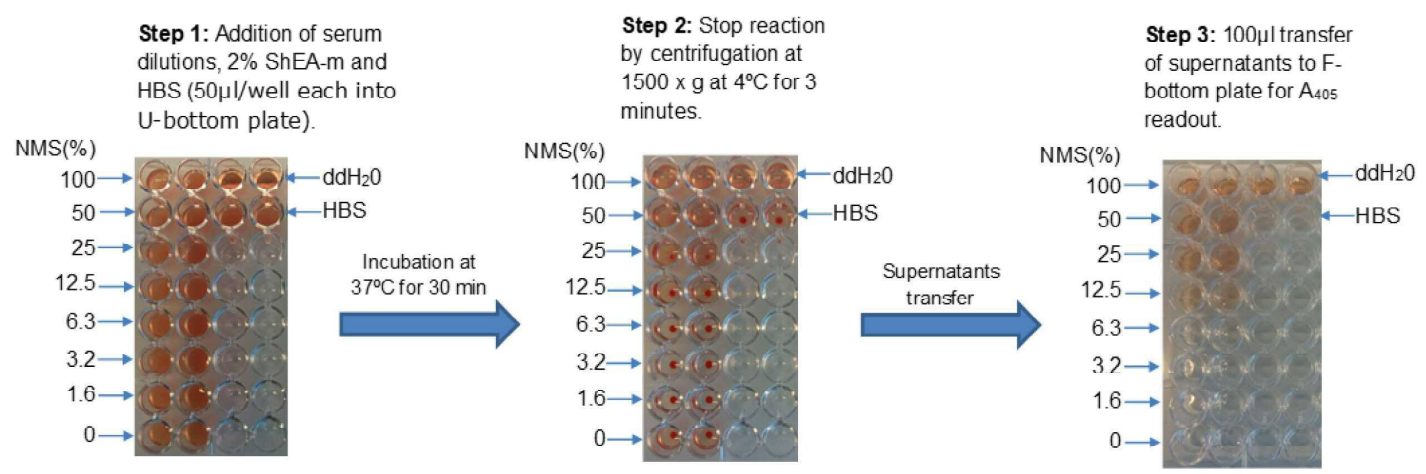

Figure 4. Pictured step-by-step workflow of the modified mouse CP CH50 assay

H. Assay method - titration of mouse component-specific $\mathrm{CH} 50$ haemolytic assay

1. Prepare serial dilution series (5-0\%; $50 \mu \mathrm{l} /$ well) of NHS, NMS, C5D, and C5D supplemented with $25 \%$ NMS in a U-bottom plate (in triplicate).

2. Add $2 \%$ ShEA suspension in HBS $(50 \mu \mathrm{l} /$ well).

3. Add $50 \mu \mathrm{l} /$ well HBS to NHS, C5D, and NMS (total volume per well: $150 \mu l$; serum concentration: $1.7-0 \%)$.

4. Prepare controls (in triplicate):
a. $0 \%$ lysis: $50 \mu \mathrm{l}$ ShEA $+100 \mu$ of HBS
b. $100 \%$ lysis: $50 \mu \mathrm{LhEA}+100 \mu \mathrm{l}$ of $\mathrm{ddH}_{2} \mathrm{O}$

5. Seal the plate and incubate at $37^{\circ} \mathrm{C}$ for $30 \mathrm{~min}$.

6. Stop the reaction by spinning down the plate at $1,500 \times g$ for $3 \mathrm{~min}$ at $4^{\circ} \mathrm{C}$.

7. Transfer $100 \mu$ l supernatant of each row to an F-bottom plate without disturbing the pelleted ShEA.

8. Measure the absorbances at $405 \mathrm{~nm}$ within $10 \mathrm{~min}$ using the plate reader; see Figure 5 for the example calculations. 


\section{biö-protocol

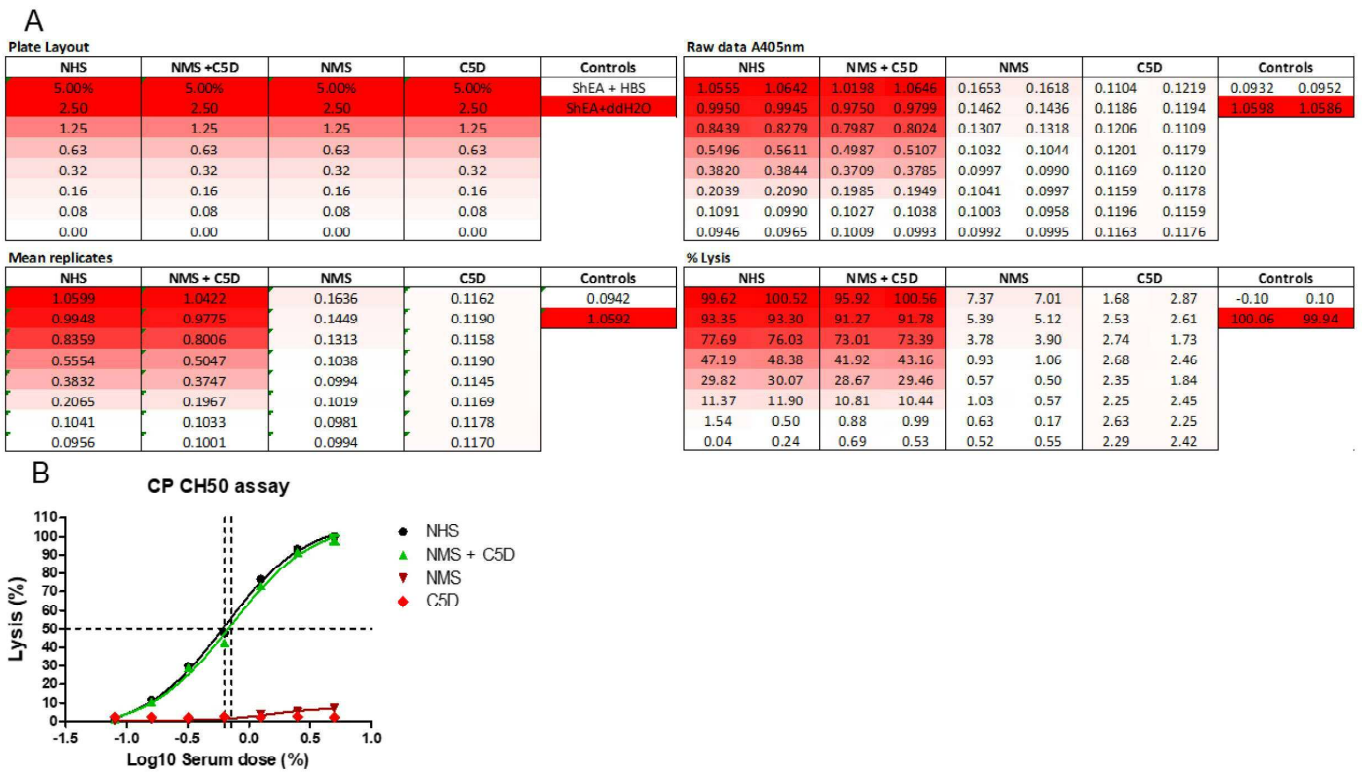

Figure 5. Example data of $\mathrm{CP}$ CH50 assay utilising human depleted sera and mouse serum (C5 as example). A. Assay plate setup and calculations; red colour indicates signal intensity. B. CH50 plotted for NMS ( $\nabla ; 5-0 \%$ ), human C5D (»), C5D supplemented with NMS $(25 \% ; \Delta)$, and NHS $(\bullet)$. The assay controls are included in the same assay. The dotted lines show the serum dose to give $50 \%$ ShEA lysis. NMS, normal male mouse serum; NHS, normal human serum; C5D, human C5 depleted serum.

I. Assay method - add back mouse component-specific $\mathrm{CP}$ CH50 haemolytic assay

1. Prepare serial dilution series (10-0\%; $50 \mu \mathrm{l} /$ well) of NHS, C5D + NMS (25\% vol:vol), and C5D + human $(75 \mu \mathrm{g} / \mathrm{ml})$ in a U-bottom plate (in triplicate).

2. Add $2 \%$ ShEA suspension in HBS $(50 \mu / /$ well).

3. Add $50 \mu \mathrm{l} /$ well HBS (total volume per well, $150 \mu \mathrm{l}$; serum concentration, 3.33-0\%)

4. Prepare controls (in triplicate):
a. $0 \%$ lysis: $50 \mu \mathrm{l} \mathrm{ShEA}+100 \mu \mathrm{l}$ of HBS
b. $100 \%$ lysis: $50 \mu \mathrm{IShEA}+100 \mu \mathrm{l}$ of $\mathrm{ddH}_{2} \mathrm{O}$

5. Seal the plate and incubate at $37^{\circ} \mathrm{C}$ for $30 \mathrm{~min}$.

6. To stop the reaction, spin down the plate at $1,500 \times g$ for $3 \mathrm{~min}$ at $4^{\circ} \mathrm{C}$.

7. Transfer $100 \mu$ l supernatant of each row to an F-bottom plate without disturbing the pelleted ShEA.

8. Measure the absorbances at $405 \mathrm{~nm}$ within $10 \mathrm{~min}$ using the plate reader; see Figure 5 for the example calculations.

\section{Data analysis}

1. Confirm controls show respectively 0 (Background) and 100\% (Maximum) lysis.

2. Calculate $\%$ Lysis in test sample as follows: 
$\%$ Lysis $=\left(\right.$ Sample $\mathrm{A}_{405}-$ Background $\left.\mathrm{A}_{405}\right) /\left(\right.$ Maximum $\mathrm{A}_{405}-$ Background $\left.\mathrm{A}_{405}\right) \times 100 \%$

See Figure 6 for the example calculations.

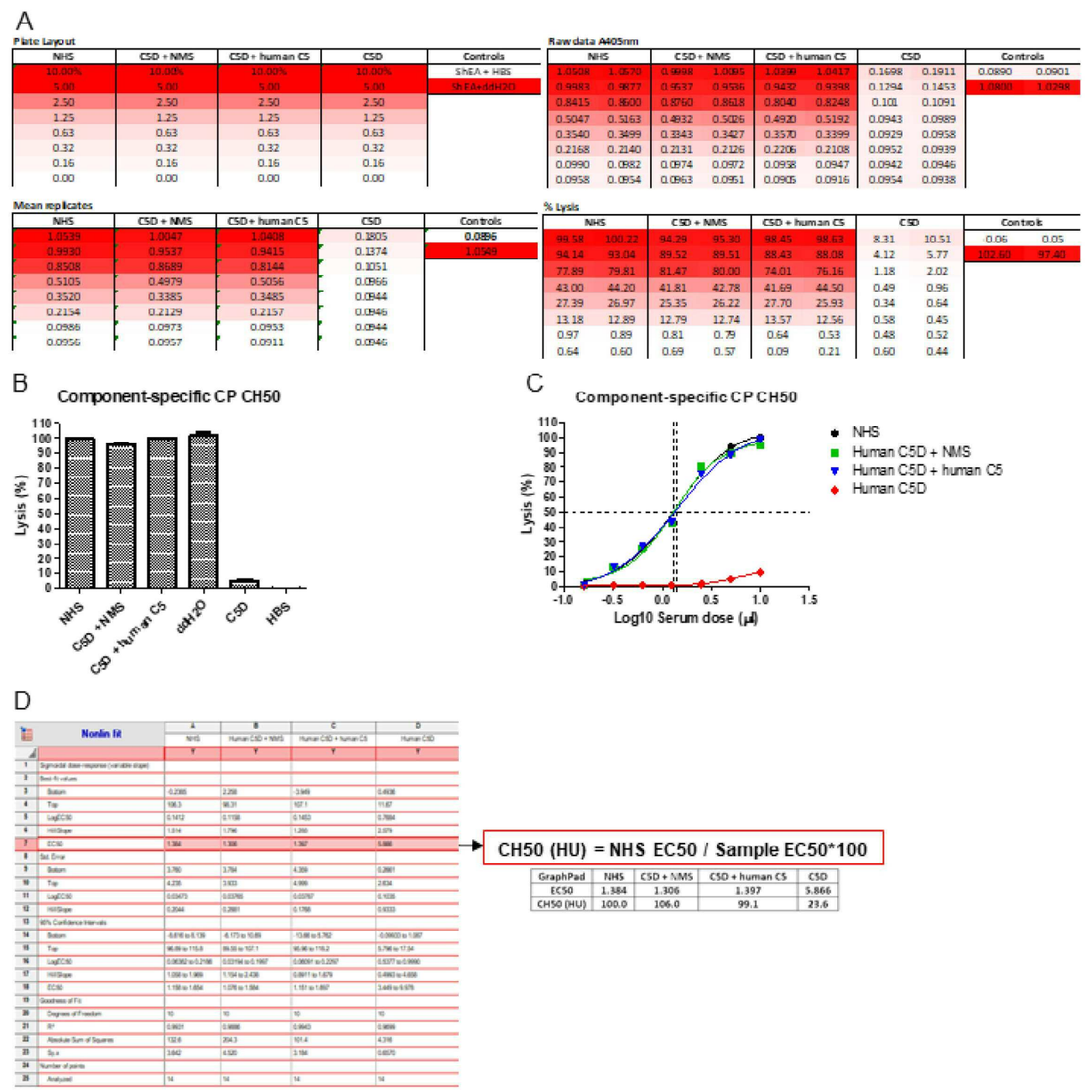

Figure 6. Example data of $\mathrm{CP}$ CH50 assay utilising human depleted sera and mouse serum. A. Assay plate setup and calculations; red colour indicates signal intensity. B. Haemolysis for samples with the highest concentration of serum $(10 \%)$, including the assay controls. C. Calculating $\mathrm{CH} 50$. The graph shows a log-log plot of $\mathrm{Y}$-axis $\%$ of lysis vs. X-axis $\%$ of diluted serum for a test sample. The broken line from the $Y$-axis intercepts this point on the hemolysis curve, and the intercept from this point to the $X$-axis permits the serum volume at $50 \%$ hemolysis to be read. The dotted lines show the serum dose to give $50 \%$ ShEA lysis. D. Data exported from GraphPad (EC50) and calculations to obtain $\mathrm{CH} 50$ values; the standard NHS sample measurement is designated a $\mathrm{CH} 50$ of $100 \mathrm{HU}$. CH50s of samples are calculated by applying the formula NHS EC50/Sample EC50 × 100 .

3. Calculate SEM \pm SD \% lysis of test triplicates using GraphPad Prism.

4. Plot dilution curves and calculate $\mathrm{CH} 50$ (the amount of serum giving $50 \%$ hemolysis) for each 
test sample (see Figure 6D).

5. Determine the statistical significance of differences between samples (e.g., using the Student's $t$-test (parametric) or one-way ANOVA/Tukey's test) compared to the appropriate control using GraphPad Prism.

\section{$\underline{\text { Notes }}$}

1. The TCS product is sheep blood diluted in Alsever's solution. To prolong viability of erythrocytes, upon receiving, the cells are pelleted by centrifugation and resuspended in fresh Alsever's solution to remove other blood products that can cause loss of viability on storage. Washed erythrocytes can be stored in Alsever's solution ( $5 \%$ vol:vol) at $4^{\circ} \mathrm{C}$ for up to 3 months.

2. ShEA and ShEA-m can be stored in Alsever's solution on ice for up to 2 weeks and for at least a week in $4^{\circ} \mathrm{C}$ refrigerator without loss of activity.

\section{Recipes}

1. HBS buffer

$\begin{array}{lll}\text { Reagent } & \text { Molarity } & \text { Mass } \\ \mathrm{HEPES} & 0.01 \mathrm{M} & 2.4 \mathrm{~g} \\ \mathrm{NaCl} & 0.15 \mathrm{M} & 8.75 \mathrm{~g} \\ \mathrm{CaCl}_{2} & 135 \mu \mathrm{M} & 0.015 \mathrm{~g} \\ \mathrm{MgCl}_{2} & 1 \mathrm{mM} & 0.1 \mathrm{~g} \\ \mathrm{ddH}_{2} \mathrm{O} & \text { n/a } & \text { Up to } 1 \mathrm{~L}\end{array}$

a. Dissolve the salts in $\sim 980 \mathrm{ml}$ of $\mathrm{ddH}_{2} \mathrm{O}$.

b. Adjust $\mathrm{pH}$ of the solution to 7.4 with $5 \mathrm{M} \mathrm{NaOH}$ (prepared by dissolving $20 \mathrm{~g} \mathrm{NaOH}$ in 100 $\mathrm{ml}$ of $\mathrm{ddH}_{2} \mathrm{O}$ ).

c. Measure the solution volume, add more $\mathrm{ddH}_{2} \mathrm{O}$, up to $1 \mathrm{~L}$.

d. Re-measure $\mathrm{pH}$ (7.4).

e. Filter via $0.2 \mu \mathrm{m}$ filter.

\section{Acknowledgments}

I would like to thank Professor Paul Morgan for his constructive criticism in preparation of this manuscript and for his ongoing support. Thank the members of the Complement Biology Group at Cardiff University for donating blood for the research. WMZ is supported by a Health and Care Research Wales Fellowship from Welsh Government. This protocol was inspired by our recent research published in Frontiers in Immunology (Zelek and Morgan, 2020). 


\section{Competing interests}

I have no conflicts of interest or competing interests.

\section{Ethics}

Mouse serum was collected under UK Home Office regulations. Human serum was collected under Medical/Dental School Research Ethics Committee regulations; informed consent obtained.

\section{References}

1. Carpanini, S. M., Torvell, M. and Morgan, B. P. (2019). Therapeutic inhibition of the complement system in diseases of the central nervous system. Front Immunol 10: 362.

2. Churchill, W. H., Weintraub, R. M., Tibor, M. D. and Rapp, H. J. (1967). Mouse complement; the effect of sex hormones and castration on two the late acting components. J Exp Med 125(4): 657-672.

3. Kotimaa, J., Klar-Mohammad, N., Gueler, F., Schilders, G., Jansen, A. and Rutjes, H, et al. (2016). Sex matters: Systemic complement activity of female C57BL/6J and BALB/CJ mice is limited by serum terminal pathway components. Mol Immunol 76:13-21.

4. Mayer, M. M. (1967). Complement and complement fixation. Exp Immunochem 133-240.

5. Menny, A., Serna, M., Boyd, C. M., Gardner, S., Joseph, A. P. and Morgan, B. P., Topf, M., Brooks, N. J. and Bubeck, D. (2018). CryoEM reveals how the complement membrane attack complex ruptures lipid bilayers. Nat Commun 9(1): 5316.

6. Moleón, M. S., Merchant, M. E., Ortega, H. H. and Siroski, P. A. (2006). Genomic view of the evolution of the complement system. Innumogenetics 58(9): 701-713.

7. Morgan, B. P. and Harris, C. L. (2015). Complement, a target for therapy in inflammatory and degenerative diseases. Nat Rev Drug Discov 14(12): 857-877.

8. Podack, E. R. and Tschopp, J. (1984). Membrane attack by complement. Mol Immunol 21(7): 589-603.

9. Rice, C. E. and Boulanger, P. (1952). The interchangeability of the complement components of different animal species. J Immunol 68(2): 197-205.

10. Serna, M., Giles, J. L., Morgan, B. P. and Bubeck, D. (2016). Structural basis of complement membrane attack complex formation. Nat Commun 7: 10587.

11. Slodkowicz, G. and Goldman, N. (2020). Integrated structural and evolutionary analysis reveals common mechanisms underlying adaptive evolution in mammals. Proc Natl Acad Sci USA;117(11): 5977-5986.

12. Zelek, W. M. and Morgan, B. P. (2020). Monoclonal Antibodies Capable of Inhibiting Complement Downstream of C5 in Multiple Species. Front Immunol 11: 612402. 
13. Zelek, W. M., Xie, L., Morgan, B. P. and Harris, C. L. (2019a). Compendium of current complement therapeutics. Mol Immunol 114:341-352.

14. Zelek, W. M., Taylor, P. R. and Morgan, B. P. (2019b). Development and characterization of novel anti-C5 monoclonal antibodies capable of inhibiting complement in multiple species. Immunology 157(4): 283-295.

15. Zelek, W. M., Harris, C. L. and Morgan, B. P. (2018). Extracting the barbs from complement assays: Identification and optimisation of a safe substitute for traditional buffers. Immunobiology 223(12): 744-749. 